\title{
Occurrence of anti-Neospora caninum and anti-Toxoplasma gondii antibodies in horses in the Pantanal of Mato Grosso, Brazil
}

\section{Ocorrência de anticorpos anti-Neospora caninum e anti-Toxoplasma gondii em equinos do Pantanal Mato-Grossense, Brasil}

\author{
Luciane Maria Laskoski ${ }^{1 *}$; Livia Saab Muraro²; Rosangela Locatelli Dittrich ${ }^{3}$; \\ Renata Azevedo Abreu'; Marilia Oliveira Koch ${ }^{4}$; Fabiana Tieme Silva \\ Rafael Hideki Hagi ${ }^{5}$
}

\begin{abstract}
This study aimed to evaluate the occurrence of anti-Neospora caninum and anti-Toxoplasma gondii antibodies in horses from Pantanal, in Mato Grosso state. Two hundred blood samples were collected from horses in Pantanal of Mato Grosso, Brazil. The samples were analyzed by IFAT for the detection of anti-Neospora caninum and anti-Toxoplasma gondii antibodies. Antibodies to $N$. caninum were found in 30 (15\%) of 200 horses in titers of 50 (25 horses), 100 (two horses), 200 (two horses), and 400 (one horse). Antibodies to T. gondii were found in five (2.5\%) of 200 horses in titers of 50 (three horses), 200 (one horse), and 400 (one horse). One animal showed antibody titers for both coccidian (titers of 200 for $N$. caninum e 400 for T. gondii). The pantaneiros horses were exposed to Neospora spp. and T. gondii. Key words: Horse, pantanal, toxoplasmosis, neosporosis, immunofluorescence
\end{abstract}

\section{Resumo}

Este estudo teve como objetivo avaliar a ocorrência de anticorpos anti-Neospora caninum. e antiToxoplasma gondii em cavalos do Pantanal, no estado de Mato Grosso. Duzentas amostras de sangue foram coletadas de equinos do Pantanal Mato-grossense, Brasil. As amostras foram analisadas pela reação de Imunofluorescência Indireta (RIFI) para pesquisa de anticorpos anti-Neospora caninum e anti-Toxoplasma gondii. Os anticorpos anti N. caninum foram detectados em $30(15 \%)$ dos 200 cavalos, nos títulos de 50 ( 25 cavalos), 100 (dois cavalos), 200 (dois cavalos) e 400 (um cavalo). Os anticorpos anti $T$. gondii foram detectados em cinco $(2,5 \%)$ dos 200 cavalos, nos títulos de 50 (três cavalos), 200 (um cavalo) e 400 (um cavalo). Em um cavalo verificou-se presença de anticorpos para ambos coccídeos (título de 200 para $N$. caninum e 400 para T. gondii). Os equinos pantaneiros foram expostos ao $N$. caninum e T. gondii.

Palavras-chave: Cavalos, pantanal, toxoplasmose, neosporose, imunofluorescência

\footnotetext{
${ }^{1}$ Discente, pós-graduação de Doutorado, Universidade Federal do Paraná, UFPR, Curitiba, PR, Brasil. E-mail: luciane-laskoski@ hotmail.com

${ }^{2}$ Prof $^{\mathrm{a}}$, Dept $^{\mathrm{o}}$ de Clínica e Cirurgia Veterinária, Universidade de Cuiabá, UNIC, Cuiabá, MT, Brasil. E-mail: liviatcho@hotmail. com

${ }^{3}$ Prof., Dept ${ }^{\circ}$ de Medicina Veterinária, UFPR, Curitiba, PR, Brasil. E-mail: roslocdi@ufpr.br

${ }^{4}$ Discentes de Pós-Graduação de Mestrado, UFPR, Curitiba, PR, Brasil. E-mail: renata_abreu_@hotmail.com; mariliakoch@ hotmail.com

5 Discentes de Especialização em Residência Multiprofissional e em Área Profissional de Saúde, UFPR, Curitiba, PR, Brasil. E-mail: fabitieme@gmail.com; rafaelhagi@hotmail.com

* Author for correspondence
} 
Neosporosis is a disease caused by the Neospora caninum and Neospora hughesi parasites, which are Apicomplexa protozoa closely related to $T$. gondii. Additionally, N. caninum is one of the most cause of abortion in cattle worldwide (DUBEY; SCHARES, 2011). Abortion and neonatal diseases are associated with N.caninum infection in horses (VILLALOBOS et al., 2012; KLIGLER et al., 2007) whereas $N$. hughesi infection is associated with neurological diseases, principally equine protozoal myeloencephalitis (EPM) (FINNO et al., 2007; KLIGLER et al., 2007). Domestic dogs and coyotes are known to be the definitive hosts of $N$. caninum, and the definitive host for $N$. hughesi has not yet been identified (DUBEY; SCHARES 2011).

There is no definitive evidence that $T$. gondii causes clinical disease in horses, although antibodies to this protozoa parasite have been reported in horses from many countries, including Brazil (DUBEY et al., 1999). Previous studies in Brazil have indicated that sero-positivity for $T$. gondii in horses ranges from 1.29 to $5.9 \%$ (LOCATELLI-DITTRICH et al., 2006; ABREU et al., 2014).

The Pantanal, considered to be the world's biggest wetland area, covers an area of $150,000 \mathrm{~km}^{2}$ situated in the upper Paraguay River Basin. The greater part lies in Brasil, divided between the states of Mato Grosso and Mato Grosso do Sul, extending into Bolivia and Paraguay. The Pantaneiro horse is a breed that has developed in this region and is widely used for many different activities related to livestock (EMBRAPA, 2005). These animals live in flooded areas for more than four months per year, and the risk of infection with contamined pasture by fecal material can be high. Disorders with neurological clinical signs in Pantanal horses are commonly diagnosed as trypanosomiasis caused by Trypanosoma evansi (SEIDL et al., 2001). $N$. caninum and $T$. gondii has never been reported in Pantaneiros horses in the Pantanal region. The objective of the present study was to determine the occurrence of anti-N. caninum and anti-T. gondii antibodies in horses from Pantanal, in Mato Grosso State.

Blood samples were collected from 200 clinically healthy horses from Poconé and Cáceres, cities of Pantanal of Mato Grosso, Brazil, in five different rural properties which have 200 $\mathrm{km}$ or more distance from each other in Southern region of the State. The horses were 120 males and 80 females. Ages ranged from 3 to 15 years. The breeds were Pantaneiros (150 horses) and crossbreeds (50 horses). The farm properties size range from $20 \mathrm{~km}^{2}$ to $8,000 \mathrm{~km}^{2}$, and all of them had history of deaths of animals with neurological signs and cases of abortion. There other animals in properties, like dogs, cats, cattle and wild animals. The blood samples were collected from the jugular vein. Sera were separated and stored at $-20^{\circ} \mathrm{C}$ until used. The indirect fluorescent antibody test (IFAT) was used to detect antibodies against $N$. caninum and $T$. gondii in the horses'serum. Slides were prepared with tachyzoites of $N$. caninum (NC1 strain) and $T$. gondii ( RH strain), as described by Locatelli Dittrich et al. (2006). Serum samples were tested at an initial dilution of 1:50, in PBS solution ( $\mathrm{pH} 7.2)$ and the positives were diluted to an endpoint titer. Conjugated anti-horse $\operatorname{IgG}$ (Sigma) was used with the dilution of 1:100 the cutoff utilized was 1:50.

Antibodies against $N$. caninum were found in $30(15 \%)$ out of 200 horses. The titers these horses were: 50 (25); 100 (two); 200 (two), and 400 (one). Thirteen females (16\%) and 17 males (14\%) were seropositive, and antibodies were found in 25 Pantaneiros and five crossbreeds horses. Antibodies to $T$. gondii were found in five males, Pantaneiros horses $(2.5 \%)$. The titers of the five horses were: 50 (three), 200 (one), and 400 (one). One animal showed antibody titers for both coccidian (titers of 200 for $N$. caninum e 400 for T. gondii. All the properties $(5 / 5-100 \%)$ had $N$. caninum positive horses, and three properties (3/5-60\%) had $T$. gondii positive horses. 
The serological tests suggest that horses from Pantanal were exposed to Neospora spp., and further studies are necessary to discern which species, $N$. caninum or $N$. hughesi, infected these animals. If the horses are $N$. hughesi-infected it would be necessary to perform the IFAT using $N$. hughesi as the antigen source (PACKHAM et al., 2002).

Antibodies to $N$. caninum were related in horses from some states in Brazil, and the seroprevalence has been reported from 2.5 to $47 \%$ (VILLALOBOS et al., 2012; LOCATELLI-DITTRICH et al., 2006). Two studies carried out in Rio de Janeiro, São Paulo, Rio Grande do Sul, and Mato Grosso, detected no antibodies to N. caninum in horses (HOANE et al., 2006; DUBEY et al., 1999). Antibodies were not found in 15 horses from Rio de Janeiro, in 70 horses from São Paulo, and in 16 horses from Rio Grande do Sul State (DUBEY et al., 1999). Additionally, antibodies were not found in 28 sera samples from horses from Mato Grosso, without information about gender and breed (HOANE et al., 2006).

In this study, the serum occurrence of antibodies against $N$. caninum was $15 \%$, similar to the another studies carried out in Rio Grande do Sul, in breeding mares (13.8\%, IFAT, title 50); in horses of different genders (15.4\%), and in carter and Crioulo horses (15.4\% and $16.3 \%$, respectively) (SANGIONI et al., 2011; TOSCAN et al., 2010). In Paraná, a similar prevalence was found in carter horses (14.4\%; IFAT, title 50) (VILLALOBOS et al., 2012). Reasons for the different seroprevalence reported in horses may be due different management conditions and/ or geographic locations. The present study is the first report of the presence of antibodies against $N$. caninum in horses from Pantanal, Mato Grosso.

In this study, antibodies against $T$. gondii were detected in only five horses $(2.5 \%)$. Antibodies to T. gondii have been reported in horses from many Brazilian states; however, seroprevalence studies also suggest that there is a low prevalence of $T$. gondii-positive serology in equine populations (DUBEY et al., 1999; EVERS et al., 2013; ABREU et al., 2014). In Rio de Janeiro and Paraná, the prevalences of antibodies against $T$. gondii were $16 \%$ and $2.7 \%$, respectively (DUBEY et al., 1999; LOCATELLI-DITTRICH et al, 2006). In São Paulo state, the prevalence of $T$. gondii in horses with ataxia was $34.7 \%$, in a modified agglutination test (STELMANN et al., 2011). In Mato Grosso do Sul and Bahia states, the seroprevalences (IFAT, title 64 ) were $32.8 \%$ and $1.5 \%$, respectively (MENDONÇA et al., 2001; LARANGEIRA et al., 1985). Using IFAT (title 16), Evers et al. (2013) found the prevalence of $11.6 \%$ in slaughtered horses from several states (Parana, Minas Gerais, Rio de Janeiro, Goiás, Mato Grosso and Mato Grosso do Sul). The highest prevalence for $T$. gondii was $41.5 \%$, in slaughtered horses of Paraná, São Paulo, Mato Grosso do Sul and Mato Grosso (IFAT, title of 16) (VIDOTTO et al., 1997). The different seroprevalences detected in horses were probably because of differences in the methodology and titles, different management conditions and/ or environments. There is the necessity for further investigation of the epidemiology of these parasites in horses of Pantanal region, mainly for the presence of dogs, cats or wild animals. sorologia

The control and prophylaxis measures necessary for bovine neosporosis, already complex, will be further complicated if wildlife plays a role in the domestic and sylvatic cycle of the parasite, as seems likely. Canids are important in the epidemiology of $N$. caninum infection because they are the only hosts reported to date that can excrete the environmentally resistant oocysts. Reports on seroprevalence are of interest because, as occurs with $T$. gondii, seropositive animals might have already shed $N$. caninum oocysts in the environment. In addition, as indicated previously, surveys of $N$. caninum infection in free-ranging canids can provide an estimation of environmental contamination and circulation of $N$. caninum in domestic and wild ecosystems.

All properties had dogs and cats as pets. Domestic dogs and Australian dingos and coyotes are the 
only known definitive host of $N$. caninum able to excrete oocysts (KING et al., 2010; GONDIM et al., 2004), however, in others wild canids little is known of $N$. caninum oocyst excretion. Recently, Dubey et al. (2011) observed that gray wolf (Canis lúpus) may also be an important link in the sylvatic cycle of $N$. caninu, because this species of wolf eliminates oocysts in the feces. Thus, perhaps other wild canids could be definitive hosts, as crab-eating fox (Cardocyon thous) and maned wolf (Chrysocyon brachyurus), which are both animals present in the Brazilian Pantanal (EMBRAPA, 2002) and identified soropositive animals for $N$. caninum (CANON-FRANCO et al., 2004), however, without studies of presence of oocysts in the faeces. Thus, this would be a possible explanation for the high percentage of seropositive horses for $N$. caninum observed in this study. With respect to $T$. gondii, there are studies demonstrating seropositivity in wild felids in Brazil, especially the jaguar (Panthera onca), widely distributed in the Brazilian Pantanal (EMBRAPA, 2002). However, these studies show only seropositivity in captivity animals (SILVA et al., 2001; RAMOS SILVA et al., 2007), and there are no comparative studies on free-living wild cats. Additionaly, there are no evaluation of shedding $T$. gondii oocysts in wild cats faeces. Thus, further studies should be conducted to assess the soropresence of $T$. gondii and N. caninum in felids and canines of Pantanal, respectively, as well as their role as definitive hosts, to establish its importance in infection of other species that cohabit the region, like the Pantanal horses.

The present study showed that horses in Pantanal region, Mato Grosso, are exposed to $T$. gondii and $N$. caninum. This study reports for the first time the presence of antibodies against these parasites in healthy pantaneiros horses.

\section{Comission of ethics and animal welfare}

Protocol number 2012-082 (CEP/Cuiabá University).

\section{References}

ABREU, R. A.; WEISS, R. R.; THOMAZ-SOCCOL, V.; LOCATELLI-DITTRICH, R.; LASKOSKI, L. M.; BERTOL, M. A.; KOCH, M. O.; ALBAN, S. M.; GREEN, K. T. Association of antibodies against Neospora caninum in mares with reproductive problems and presence of seropositive dogs as a risk factor. Veterinary Parasitology, Amsterdam, v. 202, n. 3-4, p. 128-131, 2014.

CANON-FRANCO, W. A.; YAI, L. E. O.; SOUZA, S. L. P.; SANTOS, L. C.; FARIAS, N. A. R.; RUAS, J.; ROSSI, F. W.; GOMES, A. A. B.; DUBEY, J. P.; GENNARI, S. M. Detection of antibodies to Neospora caninum in two species of wild canids, Lycalopex gymnocercus and Cerdocyon thous from Brazil. Veterinary Parasitology, Amsterdam, v. 123, n. 3-4, p. 275-277, 2004.

DUBEY, J. P.; KERBER, C. E.; GRANSTROM, D. E. Serologic prevalence of Sarcocystis neurona, Toxoplasma gondii and Neospora caninum in horses in Brazil. Journal of American Veterinary Medical Association, Illinois, v. 215, n. 7, p. 970-972, 1999.

DUBEY, J. P.; SCHARES, G. Neosporosis in animals the last five years. Veterinary Parasitology, Amsterdam, v. 180 , n. 1-2, p. 90-108, 2011.

DUBEY, J. P.; JENKINS, M. C.; RAJENDRAN, C. K.; MISKA, C. K.; FERREIRA, L. R.; MARTINS, J.; KWOK, O. C. H.; CHOUDHARY, S. Gray wolf (Canis lupus) is a natural definitive host for Neospora caninum. Veterinary Parasitology, Amsterdam, v. 181, n. 2-4, p. 382-387, 2011.

EMPRESA BRASILEIRA DE PESQUISA AGROPECUÁRIA - EMBRAPA. Revisão do conhecimento sobre ocorrência e distribuição de mamíferos do Pantanal. Corumbá: Boletim de Pesquisa e Desenvolvimento, 2002. Disponível em: <http://www. cpap.embrapa.br/publicacoes/online/DOC38.pdf>. Acesso em: 20 out. 2014.

Descrição do manejo geral de cavalos pantaneiros na região do pantanal. Corumbá: Boletim de Pesquisa e Desenvolvimento, 2005. Disponível em: $<$ http://www.cpap.embrapa.br/publicacoes/online/BP63. pdf $>$. Acesso em: 11 mar. 2013.

EVERS, F.; GARCIA, J. L.; NAVARRO, I. T.; ZULPO, L.; NINO, B. S. L.; EWALD, M. P. C.; PAGLIARI, S.; ALMEIDA, J. C.; FREIRE, R. L. Diagnosis and isolation of Toxoplasma gondii in horses from Brazilian slaughterhouses. Revista Brasileira de Parasitologia Veterinária, São Carlos, v. 22, n. 1, p. 58-63, 2013.

FINNO, C. J.; PACKHAM, A. E.; DAVID WILSON, W.; GARDNER, I. A.; CONRAD, P. A.; PUSTERLA, 
N. Effects of blood contamination of cerebrospinal fluid on results of indirect fluorescent antibody tests for detection of antibodies against Sarcocystis neurona and Neospora hughesi. Journal of Veterinary Diagnostic Investigation: Oficial Publication of the American Association of Veterinary Laboratory, Visalia, CA, v. 19, n. 3, p. 286-289, 2007.

GONDIM, L. F. O.; MCALLISTER, M. M.; PITT, W. C.; ZEMLICKA, D. E. Coyotes (Canis latrans) are definitive hosts of Neospora caninum. International Journal for Parasitology, Oxford, v. 34, n. 2, p. 159-161, 2004.

HOANE, J. S.; GENNARI, S. M.; DUBEY, J. P.; RIBEIRO, M. G.; BORGES, A. S.; YAI, L. E.; AGUIAR, D. M.; CAVALCANTE, M. G. T.; BONESI, G. L.; HOWE, D. K. Prevalence of Sarcocystis neurona and Neospora spp. infection in horses from Brazil based on presence of serum antibodies to parasita surface antigen. Veterinary Parasitology, Amsterdam, v. 136, n. 2, p. 155159, 2006

KING, J. S.; SLAPETA, J.; JENKINS, D. J.; ALQASSAB, S. E.; ELLIS, J. T.; WINDSOR, P. A. Australian dingoes are definitive host of Neospora caninum. International Journal for Parasitology, Oxford, v. 40, n. 8, p. 945-950, 2010.

KLIGLER, E. B.; SHKAP, V.; BANETH, G.; MILDENBERG, Z.; STEINMAN, A. Seroprevalence of Neospora spp. among asymptomatic horses, aborted mares and horses demonstrating neurological signs in Israel. Veterinary Parasitology, Amsterdam, v. 148, n. 2, p. 109-113, 2007.

LARANGEIRA, N.L.; ISHIZUKA, M.; HYAKUTAKE, S. Prevalência da toxoplasmose equina avaliada pela técnica de imunofluorescência indireta, Mato Grosso do Sul, Brasil. Boletin de la Oficina Sanitária Panamericana, Washington, v. 99, n. 2, p. 158-162, 1985.

LOCATELLI-DITTRICH，R.; DITTRICH，J. R.; RICHARTZ, R. R.; GASINO JOINEAU, M. E.; ANTUNES, J.; PINCKNEY, R. D.; DECONTO, I.; HOFFMANN, D. C.; THOMAZ-SOCCOL, V. Investigation of Neospora spp. and Toxoplasma gondii antibodies in mares and in precolostral foals from Paraná state, Southern Brazil. Veterinary Parasitology, Amsterdam, v. 135, n. 3-4, p. 215-221, 2006.

MENDONÇA, A. O.; CERQUEIRA, E. J. L.; ARAUJO, W. N.; SILVA, E. M.; SHIMABUKURO, F. H.; SARKIS, D. T.; SHERLOCK, I.; LANGONI, H. Inquérito sorológico para toxoplasmose em equídeos procedentes de duas regiões do estado da Bahia, Brasil. Semina: Ciências Agrárias, Londrina, v. 22, n. 2, p. 115118, 2001.
PACKHAM, A. E.; CONRAD, P. A.; WILSON, W. D.; JEANES, L. V.; SVERLOW, K. W.; GARDNER, I. A.; DAFT, B. M.; MARSH, A. E.; BLAGBURN, B. L.; FERRARO, G. L.; BARR, B. C. Qualitative evaluation of selective tests for detection of Neospora hughesi antibodies in serum and cerebrospinal fluid of experimentally infected horses. Journal of Parasitology, Laurence, v. 88, n. 6, p. 1239-1246, 2002.

RAMOS SILVA, J. C.; MARVULO, M. F.; DIAS, R. A.; FERREIRA, F.; AMAKU, M.; ADANIA, C. H.; FERREIRA NETO, J. S. Risk factors associated with sero-positivity to Toxoplasma gondii in captive neotropical felids from Brazil. Preventive Veterinary Medicine, Colorado, v. 78, n. 3-4, p. 286-295, 2007.

SANGIONI, L. A.; BOTTON, S. A.; CARGNELUTTI, J. F.; CADORE, G. C.; CEZAR, A. S.; WEIBLEN, R.; LOPES, S. T. A.; VOGEL, F. S. F. Pesquisa de anticorpos anti-Neospora spp. e anti-Herpes vírus equino em cavalos de tração do município de Santa Maria, RS, Brasil. Ciência Rural, Santa Maria, v. 41, n. 2, p. 321323, 2011

SEIDL, A. F.; MORAES, A. S.; SILVA, R. A. M. S. Trypanosoma evansi control and horse mortality in the brazilian pantanal. Memórias do Instituto Oswaldo Cruz, Rio de Janeiro, v. 96, n. 5, p. 599-602, 2001.

SILVA, J. C.; OGASSAWARA, S.; ADANIA, C. H.; FERREIRA, F.; GENNARI, S. M.; DUBEY, J. P.; FERREIRA-NETO, J. S. Seroprevalence of Toxoplasma gondii in captive neotropical felids from Brazil. Veterinary Parasitology, Amsterdam, v. 102, n. 3, p. 217-224, 2001.

STELMANN, U. J. P.; SILVA, R. C.; LANGONI, H.; BORGES, A. S.; AMORIM, A. M. Antibodies against Toxoplasma gondii in horses with history of ataxia. Revista Brasileira de Medicina Veterinária, Rio de Janeiro, v. 33, n. 4, p. 200-202, 2011.

TOSCAN, G.; CADORE, G. C.; PEREIRA, R. C. F.; SILVA, G. B.; CEZAR, A. S.; SANGIONI. L. A.; OLIVEIRA, L. S. S.; VOGEL, F. S. F. Neosporose equina: ocorrência de anticorpos anti-Neospora spp. e associação entre status sorológicos de éguas e de suas crias. Pesquisa Veterinária Brasileira, Seropédica, v. 30, n. 8, p. 641-645, 2010.

VIDOTTO, O.; KANO, F. S.; FREIRE, R. L.; MITSUKA, R.; OGAWA, L.; BONESI, G.; NAVARRO, I. T.; FRANCISCON, F. S. G. Ocorrência de anticorpos anti-Toxoplasma gondii em equinos procedentes de quatro estados (SP, PR, MS e MT) abatidos em Apucarana, PR. Semina: Ciências Agrárias, Londrina, v. 18, n. 1, p. 9-13, 1997. 
VILLALOBOS, E. M. C.; FURMAN, K. E.; LARA, of Neospora sp. antibodies in cart horses from urban M. C. C. S. H.; CUNHA, E. M. S.; FINGER, M. A.; áreas of Curitiba, Southern Brazil. Revista Brasileira de BUSCH, A. P. B.; BARROS FILHO, I. R.; DECONTO, Parasitologia Veterinária, São Carlos, v. 21, n. 1, p. 68I.; DORNBUSCH, P. T.; BIONDO, A. W. Detection 70, 2012. 